\title{
Biology and Nutritional Indexes of Spodoptera frugiperda (Lepidoptera: Noctuidae) in Saccharine Sorghum
}

\author{
Lauren M. Barcelos ${ }^{1}$, Fabrício O. Fernandes ${ }^{2}$, Caroline Lopes ${ }^{3}$, Beatriz M. Emygdio ${ }^{4}$, Ricardo Valgas ${ }^{4}$, \\ Indyra F. de Carvalho ${ }^{3}$ \& Ana Paula S. A. da Rosa ${ }^{3}$ \\ ${ }^{1}$ Centro Universitário Univates, Brazil \\ ${ }^{2}$ Universidade Estadual Paulista Júlio de Mesquita Filho \\ ${ }^{3}$ Universidade Federal de Pelotas, Brazil \\ ${ }^{4}$ Embrapa Clima Temperado, Brazil \\ Correspondence: Ana Paula Schneid Afonso da Rosa, Embrapa Clima Temperado, Brazil. Tel: 533-275-8478. \\ E-mail: ana.afonso@embrapa.br
}

Received: August 20, 2018

doi:10.5539/jas.v11n4p126

\author{
Accepted: October 30, $2018 \quad$ Online Published: March 15, 2019 \\ URL: https://doi.org/10.5539/jas.v11n4p126
}

\begin{abstract}
Saccharine sorghum has been analyzed as a supplementary prime matter for ethanol production, especially during the sugarcane off-season period. However, it has proven to be highly susceptible to insect attacks during the cultivation cycle. The fall armyworm should be emphasized due to its voracity and high damage capacity enhanced by feeding-caused decrease in photosynthetic area. Current analysis studies the biology and determines the nutritional indexes of Spodoptera frugiperda in saccharine sorghum. Cultivars of saccharine sorghum BRS 506, BRS 509 and BRS 511were evaluated. Duration and survival of the egg, caterpillar, pre-pupal and pupal phases were determined, coupled to weight of pupae and caterpillar, life span, fecundity and pre-egg laying period. Although S. frugiperda completed its life cycle on cultivars BRS 506 and BRS 511, egg-laying and egg feasibility rates were low, whereas insects did not lay eggs on cultivar BRS 509. There was no significant difference in feeding intake by $S$. frugiperda among these three sorghum cultivars. Results suggest that saccharine sorghum is not a suitable host for S. frugiperda. Biological data reveal that the three saccharine sorghum cultivars are recommended for the grain production system since the number of specimens of the next generation is low or null.
\end{abstract}

Keywords: ethanol, life cycle, fall armyworm, feed intake

\section{Introduction}

Saccharine sorghum [Sorghum bicolor (L.) Moench] is one of the most promising alternatives as a renewable prime matter for the production of ethanol due to its similarity with sugarcane (Saccharum officinarum L.) with its saccharine fleshy stem. It may be planted in places where sugarcane has failed to adapt itself, in rotation with other yearly crops and potentially planted in non-cultivated areas. Further, it may be a supplementary culture in offseason in areas with sugarcane culture, with a harvest extension of four months (Emygdio, 2010).

It should be underscored that sorghum culture is totally mechanized, from planting to harvest; grain production is around $2.5 \mathrm{t} \mathrm{ha}^{-1}$; and the product may be used for human and animal food or for the production of biofuel. Bagasse is a source of energy for industrialization, co-generation of electricity or animal forage. In fact, it contributes for favorable energy balance, with primary strategy as a crop in renewable areas, with grinding period within 45 days (Teixeira et al., 1997; Emygdio, 2010; Parrella et al., 2011).

Pest insects are highly relevant among biotic factors since they attack the plants from seeding to harvest. Damage mainly comprises decrease in stand, plant vigor and radicle system, with high lodging and drastic reduction in harvest indexes. Although several pests attack saccharine sorghum culture, the fall armyworm Spodoptera frugiperda (Smith, 1797) (Lepidoptera: Noctuidae) is one of the most damaging species for sorghum vegetative segment. The caterpillars feed on new leaves which, in turn, are damaged within the chrysalis. When the new leaves expand, symmetric lesions are detected on both sides of the foliar limbo. Caterpillars cause most damage during the last instars due to the great amount of leaves they consume (May et al., 2012; Mendes et al., 2012). 
Feeding involves several aspects in Biology, including Ecology, Behavior and Physiology. Quantitative nutrition (amount of food), qualitative nutrition (nutrients required from the chemical point of view) and secondary compounds (allelochemicals) impact insect biology in very different ways (Parra, 1991).

The study of the biology, intake and utilization of ingested food are highly relevant since they are a basic condition for insect growth, development and reproduction. In fact, quantity and quality of feed in the larval phase influence adult activity (Scriber \& Slansky, 1981; Parra, 1991).

Due to lack of information on the development of S. frugiperda in sorghum culture, current assay is an in-depth analysis on the biology and life table of this insect species, and on the determination of nutrition indexes.

\section{Methods}

The experiments were conducted at the Bioefficiency Centre of Embrapa Clima Temperado-Low Lands Experimental Station, located in the county of Capão do Leão/RS, in the period April/2014 February/2016.

Three sorghum cultivars, BRS 506, BRS 509 and BRS 511, used in the assay, were seeded in a greenhouse in 20L-pails, and management followed technical instructions of the culture (Reunião, 2013). The caterpillars derived from a cultivation bred on artificial diet (Greene et al., 1976).

\subsection{Study of Biology and Life Table}

One hundred and thirty newly test tube-hatched caterpillars were selected for each cultivar, with pieces of sorghum leaves $\left(12 \mathrm{~cm}^{2}\right)$ at phenological phase V4. Tubes were buffered with cotton wool and maintained in an air-conditioned room at $25 \pm 1{ }^{\circ} \mathrm{C}$, humidity $70 \pm 10 \%$ and $14 \mathrm{~h}$ photophase. The caterpillars were fed on sorghum leaves till the pre-pupa phase. The width of the cephalic capsule was measured daily by ocular micrometer locked to a stereoscopic microscope to determine the number of instars (Dyar, 1890). Experimental design was totally randomized.

The following variables were assessed for the analysis of biological aspects: Duration and viability of caterpillar phases, pre-pupa, pupa, adult, pre-egg laying and weight of pupa after 24 hours (males and females). Couples up to $48 \mathrm{~h}$ after emergence were formed to assess adult phase, and longevity and duration of the pre-egg-laying period were determined.

A fertility life table Silveira Neto et al. (1976) was prepared from data on the duration of the development period (egg-adult), total viability, sexual ratio, pre-egg-laying period, number of egg per day and daily mortality of males and females. Mean duration of one generation $(\mathrm{T})$, net reproduction rate (Ro), intrinsic increase rate $\left(\mathrm{r}_{\mathrm{m}}\right)$ and finite increase ratio $(\lambda)$ were calculated.

\subsection{Nutrition Indexes}

Twenty-five newly-hatched caterpillars from test tubes $(8.5 \mathrm{~cm} \times 2.5 \mathrm{~cm})$ were selected to study feed intake and use. Caterpillars were kept in an air-conditioned chamber at $25 \pm 1{ }^{\circ} \mathrm{C}$, humidity $70 \pm 10 \%$ and $14 \mathrm{~h}$ photophase, weighed and fed daily on leaves from saccharine sorghum BRS 506, BRS 509 and BRS 511. Feed wastes and feces were dried in an oven at $55-60{ }^{\circ} \mathrm{C}(24 \mathrm{~h})$ and weighed on a precision electronic scale.

When they reached maximum developmental stage (last instar), the caterpillars were removed from the test tubes, killed by freezing and taken to the oven together with diet remnants and feces in the test tube. The weight of dry matter from in-taken food and weigh gain of the caterpillars were thus obtained. A 10-test tube aliquot with diet and without caterpillars was separated to determine initial dry weight of the diet (Parra, 1991).

Methodology by Waldbauer (1968), modified by Scriber and Slansky Jr. (1981), was employed to determine quantitative nutrition indexes of the larval phase, comprising the following parameters:

- Relative Intake Rate (TCR): amount of food ingested per mg body weight of the insect per day;

- Relative Metabolic Rate (TMR): amount of food spent on metabolism per mg body weight of the insect;

- Relative Growth Rate (TCrR): indicates biomass gain by the insect in relation to its weight;

- Efficiency of Feed Conversion Ingested in Biomass (ECI): percentage of ingested food that is transformed into biomass;

- Efficiency of Feed Conversion Digested in Biomass (ECD): percentage of digested food that is converted into biomass;

- Approximate Digestibility (DA): percentage of the digested food that is effectively assimilated by the insect.

Parameter rates were calculated by gravimetry (Panizzi \& Parra, 2009). Experimental design was totally randomized, with each caterpillar considered a replication. 


\subsection{Statistical Analysis}

Data of biological parameters underwent analysis of variance; means were compared by Tukey's test ( $>0.05)$ with program Genes (Cruz, 2010).

Temporal data were compared for phase duration. Variables related to time were calculated by Survival Analysis (Lee, 1992).

Statistical analysis of consumption test was given by transforming sen arc $(x / 100)^{1 / 2}$ and data may be approximated to binomial distribution and compared by Tukey's test $(\mathrm{p}>0.05)$.

\section{Results and Discussion}

The incubation period of $S$. frugiperda eggs fed on sorghum cultivars BRS 506 and BRS 511 during the larval phase lasted three days, with no significant differences (Table 1). Results corroborated those by Rosa et al. (2012) who reported rates between 2.8 and 3.3 days when they studied the biological aspects of $S$. frugiperda fed on corn strains. There was no time duration for insects fed on cultivar BRS 509 since the adults failed to lay any eggs. Egg viability of insects fed on cultivars BRS 506 and BRS 511 was $57.0 \%$ and $17.0 \%$ respectively, with significant difference (Table 1). Viability from cultivar BRS 511 was similar to that by Fernandes (2003), between 18.4 and $24.0 \%$ when insects were fed on conventional corn, and between 16.0 and $19.3 \%$ with modified corn. However, the above differs from results by Sarro (2006) with viabilities over $79.0 \%$ when corn leaves and several cotton cultivars were supplied to $S$. frugiperda. Since adults deposited few eggs coupled to low viability, it should be highlighted that the nutritional content of saccharine sorghum cultivars was not adequate for the fall armyworm. The above corroborates the fact that several species acquire nutrition resources for reproduction during the larval phase and invested energy resources may contribute towards vitellogenesis and egg maturation process (Chapman, 1998).

Table 1. Duration and viability of egg phase of Spodoptera frugiperda in saccharine sorghum cultivars in laboratory

\begin{tabular}{lll}
\hline Cultivars & Duration (days) & Viability $(\%)$ \\
\hline BRS 506 & $3.0 \pm 0.47 \mathrm{a}^{1}(\mathrm{n}=120)$ & $57.5 \pm 8.60 \mathrm{a}^{2}$ \\
BRS 511 & $3.0 \pm 0.01 \mathrm{a}(\mathrm{n}=163)$ & $17.0 \pm 8.76 \mathrm{~b}$ \\
$\mathrm{CV}^{3}$ & 23.5 & 25.4 \\
\hline
\end{tabular}

Note. ${ }^{1}$ Means followed by small letters in the column do not differ by Tukey's test $(\mathrm{p}>0.05) .{ }^{2}$ Data transformed to $(x+0.5)^{1 / 2} \cdot{ }^{3}$ Coefficient of variation.

The larval phase for insects fed on sorghum BRS 509 and 511 lasted for 31.8 and 32.4 days, which was significantly different from duration with cultivar BRS 506 (Table 2) at 19.5 days. Different from results by Giolo et al. (2002) who assessed fall armyworm populations from several places and obtained larval duration of 16.5 days for caterpillars fed on corn. Delay in the duration of the larval phase is normally verified by reduced intake of feed, frequently due to one or more inhibitors in the food or to nutritional inadequacy of the feed substrate (Martinez \& Emden, 2001).

Table 2. Duration, viability and weight of larval phase of Spodoptera frugiperda in saccharine sorghum cultivars in laboratory

\begin{tabular}{llll}
\hline Cultivars & Duration (days) & Viability $(\%)$ & Weight $(\mathrm{mg})$ \\
\hline BRS 506 & $19.5 \pm 1.53 \mathrm{~b}^{1}(\mathrm{n}=130)$ & $20.0 \pm 7.24 \mathrm{~b}^{2}$ & $0.10 \pm 0.001 \mathrm{a}^{2}$ \\
BRS 509 & $31.8 \pm 2.17 \mathrm{a}(\mathrm{n}=130)$ & $20.0 \pm 6.46 \mathrm{~b}$ & $0.10 \pm 0.004 \mathrm{a}$ \\
BRS 511 & $32.4 \pm 0.98 \mathrm{a}(\mathrm{n}=130)$ & $80.0 \pm 3.51 \mathrm{a}$ & $0.20 \pm 0.001 \mathrm{a}$ \\
CV\% $^{3}$ & 66.1 & 21.6 & 100.3 \\
\hline
\end{tabular}

Note. ${ }^{1}$ Means followed by small letters in the column do not differ by Tukey's test $(\mathrm{p}>0.05) .{ }^{2}$ Data transformed to $(x+0.5)^{1 / 2} \cdot{ }^{3}$ Coefficient of variation.

Survival analysis showed that caterpillars fed on cultivar BRS 511 may prolong the feed period up to 40 days; BRS 506 up to 60 days and BRS 509 up to 80 days. The above facts evidence that even if sorghum cultivars are 
not nutritionally fit for adequate development of the insects, the caterpillars may remain in the crops, continuously feeding and causing damage throughout the entire period (Figure 1).

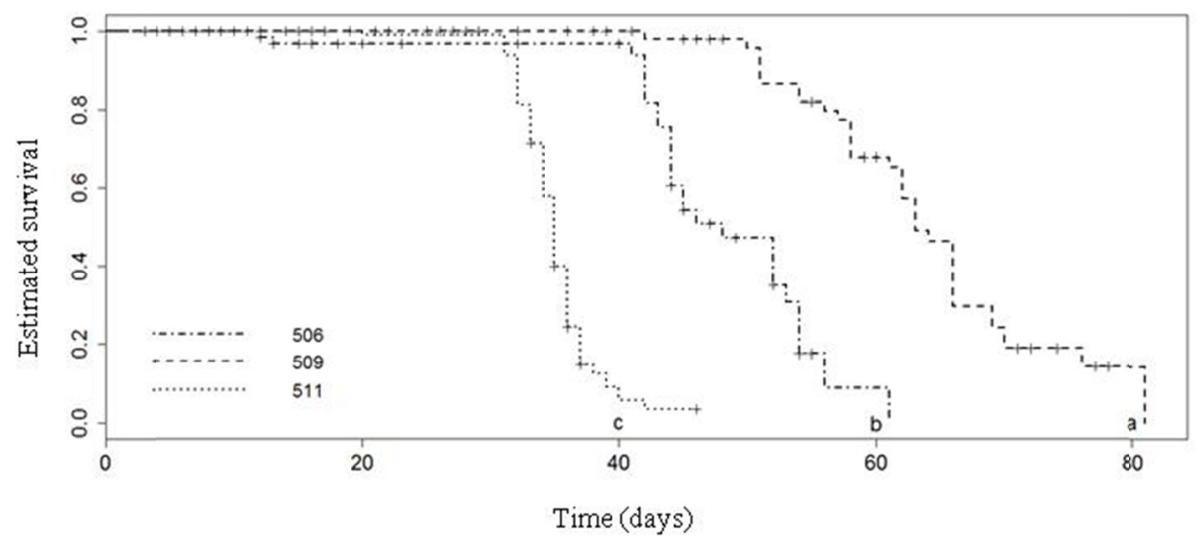

Figure 1. Estimated survival of caterpillars of Spodoptera frugiperda in cultivars of saccharine sorghum

Most caterpillars fed on cultivar BRS 511 completed their cycle in contrast to those fed on the other cultivars. In fact, they scarcely changed phase, with significant difference for the larval viability in the cultivars (Table 2). Other rates were reported for larval viability in different hosts, such as corn $(85.0 \%)$, grain-bearing sorghum (77.0\%), wild sorghum (80.0\%), soybean (83.0\%) and palisade grass (68.0\%) (Sá et al., 2009).

There was no significant difference for weight on the $14^{\text {th }}$ day of the caterpillar phase, with rates well below those registered by Busato et al. (2005) when they fed S. frugiperda caterpillars with corn leaves from different localities (Table 2). Caterpillar fed on cultivar BRS 511 gained more weight, probably due to the fact that nutritional contents of the cultivar enhanced its growth when compared to other cultivars.

The graph method demonstrated that caterpillars fed on cultivars BRS 506 and BRS 511 passed through 5 instars and those fed on BRS 509 passed through 3 larval instars (Figure 2). The above confirmed the hypotheses formulated by the coefficient of determination $\left(\mathrm{R}^{2}\right)$ acceptable above $80 \%$, and by Dyar constant estimate $(\mathrm{K})$ within the interval 1.1 - 1.9 (Table 3) (Parra \& Haddad, 1989).

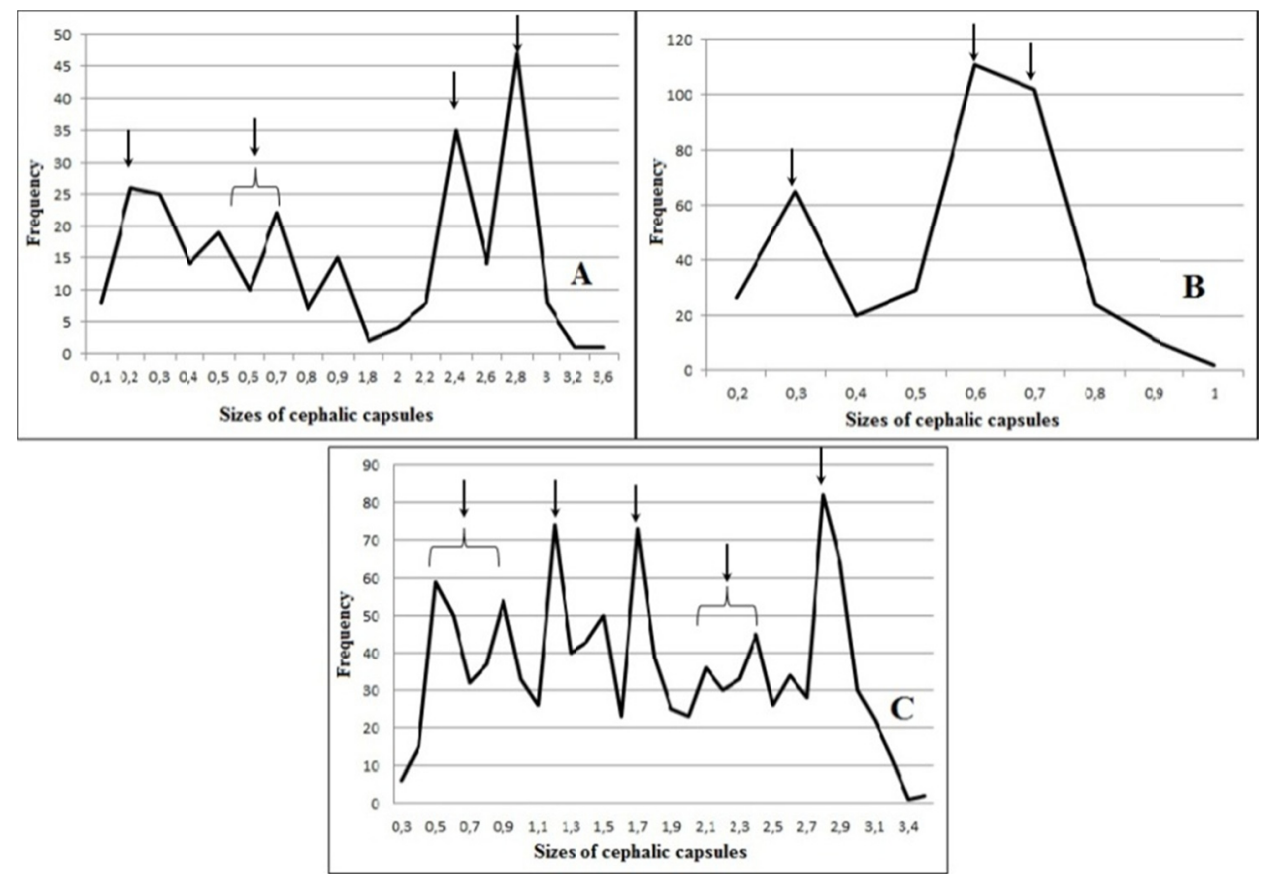

Figure 2. Distribution of frequency of sizes of cephalic capsules of Spodoptera frugiperda in (A) sorghum BRS 506; (B) sorghum BRS 509; (C) sorghum BRS 511 
Table 3. Number of instars, growth ratio $(\mathrm{K})$ and coefficient of determination $\left(\mathrm{R}^{2}\right)$ for Spodoptera frugiperda in saccharine sorghum cultivars

\begin{tabular}{llll}
\hline Cultivars & Number of instars & $\mathrm{K}$ & $\mathrm{R}^{2}(\%)$ \\
\hline BRS 506 & 5 & 1.75 & 99.0 \\
BRS 509 & 3 & 1.44 & 100.0 \\
BRS 511 & 5 & 1.36 & 100.0 \\
\hline
\end{tabular}

The number of instars in holometabolous insects is not constant and varies between 4 and 8 . The fact that caterpillars fed on sorghum BRS 509 reached only 3 larval instars may be related to the cultivar's nutritional value, even though other factors may alter the number of instars, such as gender, temperature and cultivation form (Parra \& Haddad, 1989).

The caterpillars fed on leaves of saccharine sorghum remained in the pre-pupa phase for an average of 1.6-2.3 days (Table 4), differing one from another. The rate is similar to that registered by Lopes et al. (2008), averaging 2 days for $S$. frugiperda fed on manioc leaves. The viability of the pre-pupa phase was 78.0, 20.0 and $91.0 \%$ respectively for caterpillars fed on sorghum BRS 506, BRS 509 and BRS 511, with significant difference between them. Cultivar BRS 509 had the lowest viability rate (Table 4).

Table 4. Duration and viability of the pre-pupa phase of Spodoptera frugiperda in saccharine sorghum cultivars in laboratory

\begin{tabular}{lll}
\hline Cultivars & Duration (days) & Viability (\%) \\
\hline BRS 506 & $2.3 \pm 0.66 \mathrm{a}^{1}(\mathrm{n}=28)$ & $78.0 \pm 1.75 \mathrm{a}$ \\
BRS 509 & $1.8 \pm 0.19 \mathrm{~b}(\mathrm{n}=35)$ & $20.0 \pm 3.76 \mathrm{~b}$ \\
BRS 511 & $1.6 \pm 0.04 \mathrm{~b}(\mathrm{n}=100)$ & $91.0 \pm 3.25 \mathrm{a}$ \\
CV\% & 84.8 & 43.2 \\
\hline
\end{tabular}

Note. ${ }^{1}$ Means followed by small letters in the column do not differ by Tukey's test $(\mathrm{p}>0.05) .{ }^{2}$ Coefficient of variation.

However, estimate survival of this phase may reach up to 12 days for insects fed on sorghum BRS 506 (Figure 3), which demonstrated that diet during the larval phase is less fit, with greater time for the accumulation of nutrient reserves required by the insects during this phase of its life cycle.

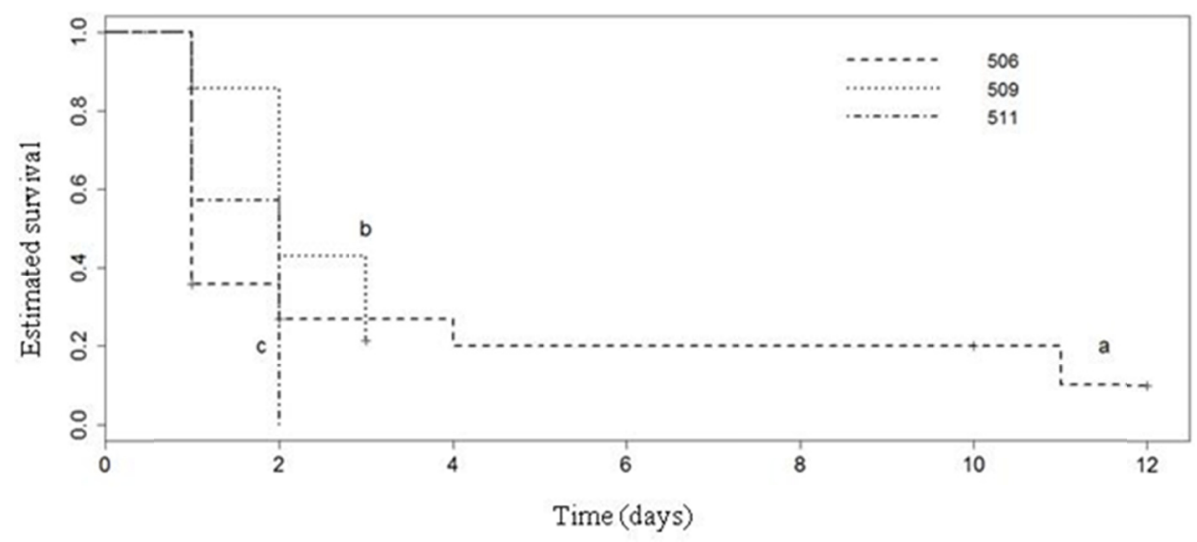

Figure 3. Estimated survival of Spodoptera frugiperda pre-pupa in saccharine sorghum cultivars

There was a significant difference in the pupal phase for cultivar BRS 506, with mean time at 11.6-12.0 days, as reported by Botton et al. (1998) who evaluated the feed preference of fall armyworm with mean time 12.9 and 12 days for rice and gulf cockspur grass. No significant difference existed for viability. However, mean weight of the pupas from sorghum cultivar BRS 511 was greater and differed from that of the other cultivars, even though 
rates were lower than those by Botton et al. (1998). The later reveals diet influence and, consequently, lighter pupae which produced smaller and weaker adults (Table 5).

Table 5. Duration, viability and weight of pupal phase of Spodoptera frugiperda in saccharine sorghum cultivars in laboratory

\begin{tabular}{llll}
\hline Cultivars & Duration (days) & Viability (\%) & Weight (mg) \\
\hline BRS 506 & $12.0 \pm 1.89 \mathrm{~b}^{1}(\mathrm{n}=23)$ & $82.6 \pm 3.39 \mathrm{a}$ & $80.0 \pm 0.001 \mathrm{~b}$ \\
BRS 509 & $11.7 \pm 0.71 \mathrm{a}(\mathrm{n}=7)$ & $100.0 \pm 0.81 \mathrm{a}$ & $80.0 \pm 0.003 \mathrm{~b}$ \\
BRS 511 & $11.6 \pm 0.09 \mathrm{a}(\mathrm{n}=100)$ & $89.5 \pm 3.14 \mathrm{a}$ & $120.0 \pm 0.01 \mathrm{a}$ \\
$\mathrm{CV} \%$ & 13.0 & 34.4 & 35.4 \\
\hline
\end{tabular}

Note. ${ }^{1}$ Means followed by small letters in the column do not differ by Tukey's test $(\mathrm{p}>0.05) .{ }^{2}$ Coefficient of variation.

Survival analysis demonstrated that duration of pupal phase may be extended up to 15 days for cultivars BRS 509 and BRS 511 (Figure 4). Studies by Pinheiro et al. (2008) indicate that duration of the pupa phase varies between 5 and 20 days, depending on the temperature. In low temperatures $\left(20^{\circ} \mathrm{C}\right)$, duration is greater and the period decreases in higher temperatures $\left(32^{\circ} \mathrm{C}\right)$, showing influence of temperature and the insect's capacity in surviving thermal amplitude.

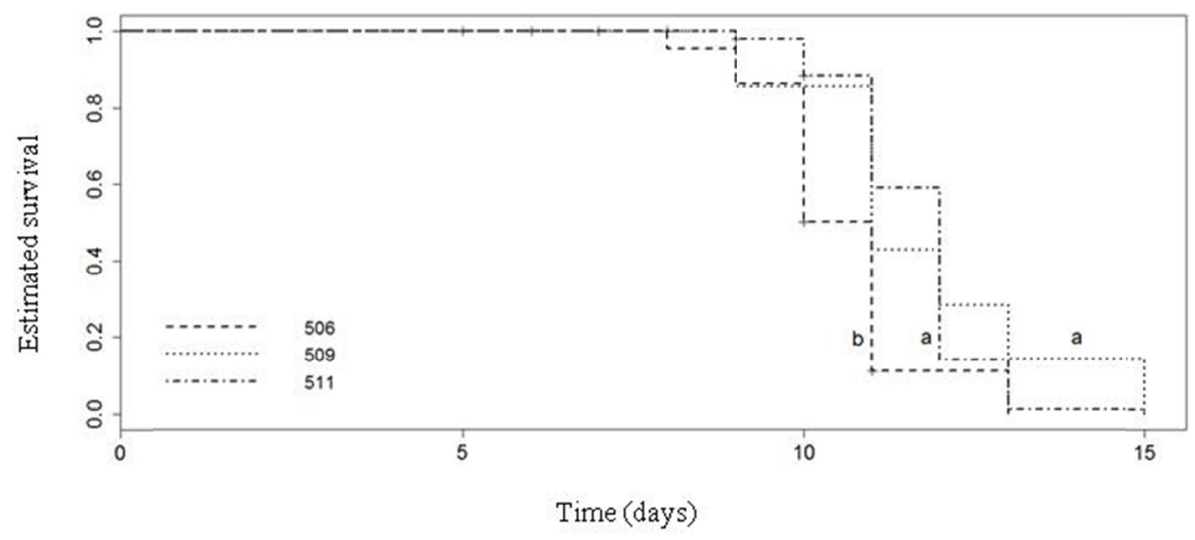

Figure 4. Estimated survival of duration of Spodoptera frugiperda pupa in saccharine sorgum cultivars

Adults' estimated survival may extend up to 40 days when insects in the immature phase fed on leaves of cultivar BRS 511 (Figure 5). However, mean duration was 12.6, 6.4 and 15.1 days for insects bred on cultivars BRS 506, BRS 509 and BRS 511, respectively. Results are not significantly different among themselves (Table 6) and are similar to those by Rosa et al. (2012) who reported a variation in duration between 14 and 32 days, according to corn strain supplied to the fall armyworm. 


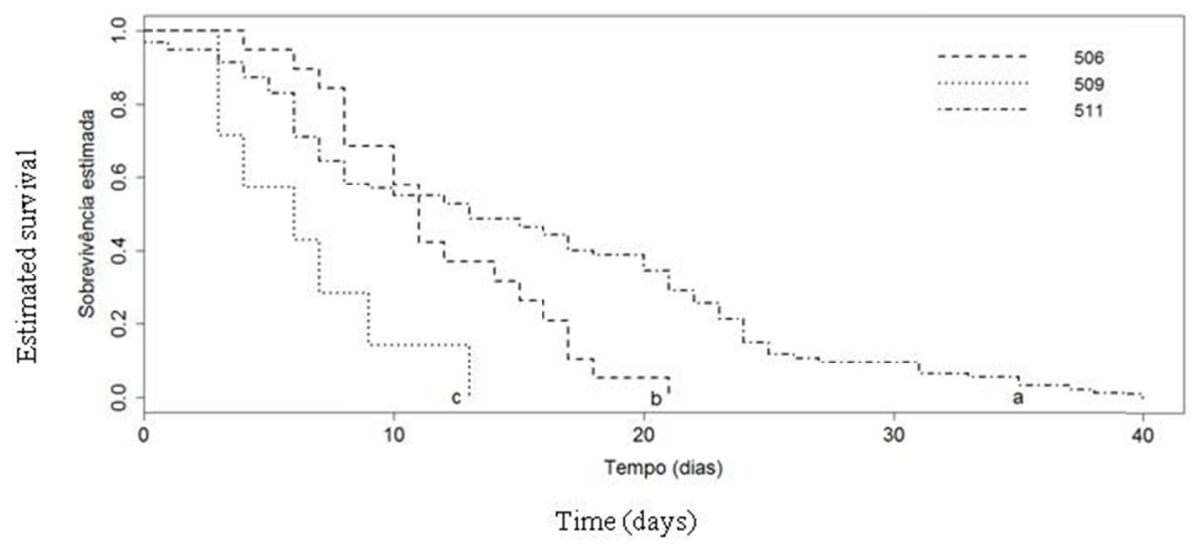

Figure 5. Estimated survival of duration in Spodoptera frugiperda adults fed on saccharine sorghum cultivars

Gender ratio (Table 6) for insects fed on sorghum BRS 511 reached 0.44, with a greater number of males in the population, very similar to result given by Lopes et al. (2008) in their studies on the biology of $S$. frugiperda on cassava leaves. According to Parra et al. (1983), feeding is not beneficial for the insect's development due to male prevalence in the population.

Table 6. Duration of adult phase and gender ratio of Spodoptera frugiperda in saccharine sorghum cultivars in laboratories

\begin{tabular}{lll}
\hline Cultivars & Duration (days) & Gender ratio (\%) \\
\hline BRS 506 & $12.6 \pm 1.05 \mathrm{a}^{1}(\mathrm{n}=19)$ & - \\
BRS 509 & $6.4 \pm 1.37 \mathrm{a}(\mathrm{n}=7)$ & - \\
BRS 511 & $15.1 \pm 1.02 \mathrm{a}(\mathrm{n}=90)$ & 0.44 \\
CV\% ${ }^{2}$ & 64.8 & -
\end{tabular}

Note. ${ }^{1}$ Means followed by small letters in the column do not differ by Tukey's test $(\mathrm{p}>0.05) .{ }^{2}$ Coefficient of variation.

Net reproduction rate (Ro) for insects fed on cultivar BRS 511 reached 5.1, very similar to that reported by Rosa et al. (2012) with 4.5 for corn strain. However, increase in population developed in the cultivar is low since results in the same assay evidenced that net rate of reproduction may reach a maximum of 20.2, and indicates feed influence on reproduction parameters. Busato et al. (2005) registered Ro $=361.5$ for a population fed on corn in adjacent areas and $\mathrm{Ro}=504.6$ in populations fed on rice in isolated areas.

Mean duration of one generation (T) was 62.1 days, similar to result by Rosa et al. (2012), with rates close to 60.1 days for fall armyworm developed on corn strain.

Intrinsic growth rate $\left(\mathrm{r}_{\mathrm{m}}\right)$ was 0.026 and finite growth rate $(\lambda)$ reached 1.027 , very close to rates by Rosa et al. (2012) who registered $r_{m}=0.027$ and $\lambda=1.027$ for S. frugiperda population fed on corn leaves. Maximum growth rate for the fall armyworm occurred on the 65th day (Figure 6). 


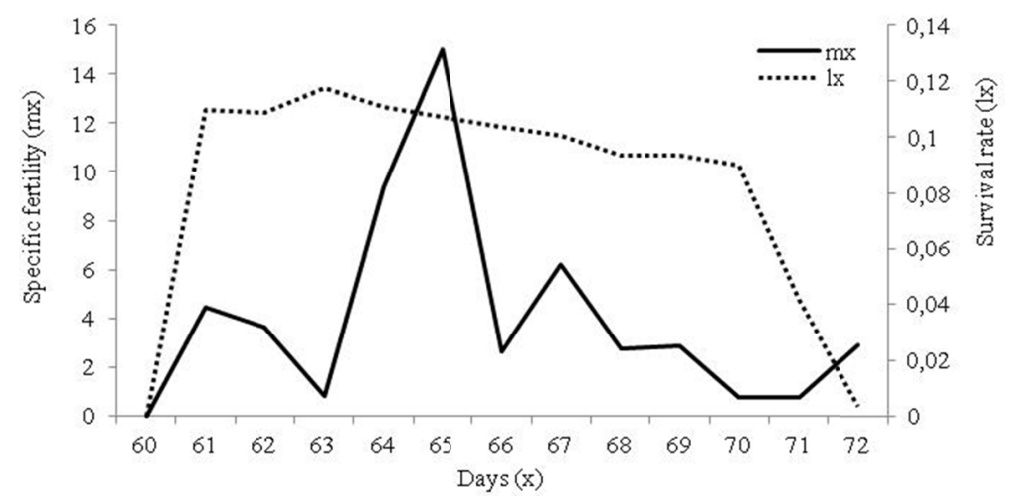

Figure 6. Specific fertility $(\mathrm{mx})$ and survival rate (lx) of Spodoptera frugiperda in saccharine sorghum BRS 511

There was no significant difference for parameters evaluated in intake test (Table 7), except death rate (Table 8). In fact only few caterpillars fed on cultivars BRS 506 and BRS 509 reached the pre-pupa phase. Result fits the biology of $S$. frugiperda, where caterpillars fed on the above two cultivars had scanty success in development.

Table 7. Duration of larval phase (T), ingested feed (I), produced feces (F), weight gain (B), assimilated (I-F) and metabolized feed $(\mathrm{M})( \pm \mathrm{EP})$ of Spodoptera frugiperda fed on saccharine sorghum

\begin{tabular}{llll}
\hline \multirow{2}{*}{ Parameters } & \multicolumn{3}{c}{ Cultivars } \\
\cline { 2 - 4 } & BRS 506 & BRS 509 & BRS 511 \\
\hline T & $40.6 \pm 23.40 \mathrm{a}^{1}$ & $56.0 \pm 1.00 \mathrm{a}$ & $43.0 \pm 12.00 \mathrm{a}$ \\
I & $0.16 \pm 0.09 \mathrm{a}$ & $0.51 \pm 0.02 \mathrm{a}$ & $0.65 \pm 0.18 \mathrm{a}$ \\
$\mathrm{F}$ & $0.10 \pm 0.05 \mathrm{a}$ & $0.39 \pm 0.04 \mathrm{a}$ & $0.35 \pm 0.09 \mathrm{a}$ \\
$\mathrm{B}$ & $2.0 \pm 0.03 \mathrm{a}$ & $20.0 \pm 0.00 \mathrm{a}$ & $20.0 \pm 0.06 \mathrm{a}$ \\
$\mathrm{I}-\mathrm{F}$ & $0.06 \pm 0.03 \mathrm{a}$ & $0.11 \pm 0.05 \mathrm{a}$ & $0.29 \pm 0.08 \mathrm{a}$ \\
M & $0.05 \pm 0.03 \mathrm{a}$ & $0.09 \pm 0.05 \mathrm{a}$ & $0.27 \pm 0.07 \mathrm{a}$ \\
\hline
\end{tabular}

Note. ${ }^{1}$ Means followed by small letters in the column do not differ by Tukey's test $(\mathrm{p}>0.05)$.

Table 8. Relative consumption rate (RCR), relative metabolic rate (RMR), growth ratio (RGR), apparent digestibility (AD), efficiency of ingested food conversion (ECI), efficiency of digested food conversion (ECD), metabolic rates (100-ECD) of Spodoptera frugiperda fed on saccharine sorghum

\begin{tabular}{llll}
\hline \multirow{2}{*}{ Nutritional indexes } & \multicolumn{3}{c}{ Cultivars } \\
\cline { 2 - 4 } & BRS 506 & BRS 509 & BRS 511 \\
\hline RCR (g/g/dia) & $0.43 \pm 0.24 \mathrm{a}^{1}$ & $1.01 \pm 0.42 \mathrm{a}$ & $0.94 \pm 0.26 \mathrm{a}$ \\
RMR (g/g/dia) & $0.15 \pm 0.09 \mathrm{a}$ & $0.26 \pm 0.22 \mathrm{a}$ & $0.40 \pm 0.11 \mathrm{a}$ \\
RGR (g/g/dia) & $0.07 \pm 0.004 \mathrm{a}$ & $0.03 \pm 0.01 \mathrm{a}$ & $0.03 \pm 0.09 \mathrm{a}$ \\
AD (\%) & $36.7 \pm 21.2 \mathrm{a}$ & $22.5 \pm 10.4 \mathrm{a}$ & $34.8 \pm 9.6 \mathrm{a}$ \\
ECI (\%) & $1.8 \pm 1.0 \mathrm{a}$ & $3.6 \pm 0.5 \mathrm{a}$ & $4.5 \pm 1.2 \mathrm{a}$ \\
ECD $(\%)$ & $5.2 \pm 3.0 \mathrm{a}$ & $25.4 \pm 10.0 \mathrm{a}$ & $29.5 \pm 8.2 \mathrm{a}$ \\
$100-$ ECD $(\%)$ & $94.7 \pm 54.7 \mathrm{a}$ & $74.5 \pm 10.0 \mathrm{a}$ & $70.4 \pm 19.5 \mathrm{a}$ \\
Death rate $(\%)$ & $88.0 \mathrm{~b}$ & $88.0 \mathrm{~b}$ & $48.0 \mathrm{a}$ \\
\hline
\end{tabular}

Note. ${ }^{1}$ Means followed by small letters in the column do not differ by Tukey's test $(\mathrm{p}>0.05)$.

The smallest relative consumption rate (RCR), which is the amount of feed ingested per gram of body weight of the insect, and relative metabolic rate (RMR), which is , the amount of feed spent in metabolism (Table 8), were calculated for caterpillars fed on sorghum leaves of BRS 506, in which they had the highest relative growth rate (RGR). The above shows biomass gain proportionate to weight although rate was well below that reported by Souza et al. (2001) who evaluated the performance of fall armyworm in natural diet by these measurements.

In current study, apparent digestibility (AD), the percentage of food ingested and effectively assimilated by the insect, had lower percentages than those registered by Busato et al. (2002) who reported these indexes for the fall armyworm fed on corn and rice leaves. 
Caterpillars with the smallest ingested feed conversion efficiency (ECI), which is, the percentage of ingested feed by the insect and transformed in biomass, and low efficiency of digested food conversion (ECD), which is, the percentage of digested feed converted into the biomass of the insect, had a higher metabolic rate. Results (Table 8) are similar to those registered by Crócomo and Parra (1985) who studied food consumption and use in different hosts, reporting lower ECI and ECD and higher metabolic rates for caterpillars fed on corn leaves.

\section{Conclusions}

Although S. frugiperda completed its life cycle when fed on cultivars BRS 506 and BRS 511, egg laying is rare and proves that hosts are scantily fit for the development of the insect. Moreover, cultivar BRS 509 is not fit for the development of the fall armyworm. Current analysis confirmed that $S$. frugiperda caterpillars (though polyphage) fed on leaves of saccharine sorghum cultivars evidenced low capacity of compensating nutritional contents supplied by the plant.

Based on S. frugiperda biological data, the use of the three saccharine sorghum cultivars (BRS 506; BRS 509; BRS 511) may be recommended for the production of grain. If fall armyworm occurs, it may be inferred that, although the insect completes its life cycle feeding on cultivar BRS 506 and 511, sorghum cultivars are not favorable feed for $S$. frugiperda. If a severe attack at the onset of crop development occurs, heavy liabilities may occur due to stand decrease.

\section{References}

Botton, M., Carbonari, J. J., Garcia, M. S., \& Martins, J. F. S. (1998). Preferência alimentar e biologia de Spodoptera frugiperda (J. E. Smith, 1797) (Lepidoptera: Noctuidae) em arroz e capim-arroz. Anais da Sociedade Entomológica do Brasil, 27(2), 207-212. https://doi.org/10.1590/S0301-80591998000200006

Busato, G. R., Grützmacher, A. D., Garcia, M. S., Giolo, F., \& Martins, A. (2002). Consumo e utilização de alimento por Spodoptera frugiperda (J.E. Smith) (Lepidoptera: Noctuidae) originária de diferentes regiões do Rio Grande do Sul, das culturas do milho e do arroz irrigado. Neotropical Entomology, 31(4), 525-529. https://doi.org/10.1590/S1519-566X2002000400003

Busato, G. R., Grützmacher, A. D., Giolo, F. P., Zotti, M. J., \& Junior, G. S. (2005). Biologia comparada de populações de Spodoptera frugiperda (J. E. Smith) (Lepidoptera: Noctuidae) em folhas de milho e arroz. Neotropical Entomology, 34(5), 743-750. https://doi.org/10.1590/S1519-566X2005000500005

Chapman, R. F. (1998). The insects: Structure and function (4th ed.). Cambridge: Cambridge University Press. https://doi.org/10.1017/CBO9780511818202

Cruz, C. D. (2010). Programa Genes-Aplicativo computacional em genética e estatística. Retrieved from https://www.ufv.br/dbg/genes/genes.htm 2010

Dyar, H. G. (1890). The number of molts of lepidopterous larvae. Psyche, 5, 420-422. https://doi.org/10.1155/ $1890 / 23871$

Emygdio, B. M. (2016). Produção de etanol a partir de sorgo sacarino. Retrieved from http://www.infobibos. com/Artigos/2010_4/sorgo/index.htm

EPPO (European and Mediterranean Plant Protection Organization). (1981). Data sheetson quarantine organisms $n^{\circ}$ 110: Helicoverpa armigera (Bulletin, 11). Paris: EPPO.

Fernandes, O. D. (2003). Efeito do milho geneticamente modificado (MON810) em Spodoptera frugiperda (J. E. Smith, 1797) e no parasitóide de ovos Trichogramma spp. (Doctoral dissertation). Retrieved from http://www.teses.usp.br/teses/disponiveis/11/11146/tde-12052003-141132/pt-br.php

Giollo, F. P., Grutzmacher, A.D., Garcia, M. S., \& Busato, G. R. (2002). Parâmetros biológicos de Spodoptera frugiperda (J. E. Smith, 1797) (Lepidoptera: Noctuidae) oriundas de diferentes localidades e hospedeiros. Revista Brasileira de Agrociência, 8, 221-224.

Greene, L. G., Lepla, N. C., \& Dickerson, W. A. (1976). Velvetbean caterpillar: a rearing procedure and artificial medium. Journal of Economic Entomology, 69(342), 488-497. https://doi.org/10.1093/jee/69.4.487

Lee, E. T. (1992). Statistical Methods for Survival Data Analysis. Ed. John Wiley \& Sons.

Lopes, G. S., Lemos, R. N. S., Machado, K. K. G., Maciel, A. A. S., \& Ottati, A. L. T. (2008). Biologia de Spodoptera frugiperda (J. E. Smith) (Lepidoptera: Noctuidae) em folhas de mandioca (Manihot esculenta Crantz). Caatinga, 21(3), 134-140. 
Martinez, S. S., \& Emden, H. F. (2001). Van Growth disruption, abnormalities and mortality of Spodoptera littoralis (Boisduval) (Lepidoptera: Noctuidae) caused by Azadirachtin. Neotropical Entomology, 30(1), 113-125. https://doi.org/10.1590/S1519-566X2001000100017

May, A., Mantovani, E. C., Durães, F. O. M., Vasconcellos, J. H., Parrella, F. A. C., Schaffert, R. E., \& Parentoni, D. N. (2012). Seminário Temático Agroindustrial de Produção de Sorgo Sacarino para Bioetanol. Anais: Embrapa Milho e Sorgo, Sete Lagoas.

Mendes, S. M., Viana, P. A., Cruz, I., \& Waquil, J. M. (2012). Controle de Pragas. In A. May, F. O. M. Durães, I. A. Pereira Filho, R. E. Schaffert, \& R. A. da C. Parrella (Eds.). Sistema Embrapa de produção de sorgo para bioetanol: Sistema BRS1G-Tecnologia Qualidade Embrapa. Sete Lagoas: Embrapa Milho e Sorgo.

Panizzi, A. R., \& Parra, J. R. P. (2009). Bioecologia e nutrição de insetos-Base para o manejo 359 integrado de pragas. Embrapa Informação Tecnológica, Brasília.

Parra, J. R. P. (1991). Consumo e utilização de alimento por insetos. In A. R. Panizzi, \& J. R. P. Parra (Eds.), Ecologia nutricional de insetos e suas implicações no manejo de pragas. São Paulo: Manole.

Parra, J. R. O., \& Haddad, M. L. (1989). Determinação do número de instares de inseto. FEALQ, ESALQ-USP.

Parra, J. R. P., Melo, A. B. P., Magalhaes, B. P., Silveira Neto, S., \& Botelho, P. S. M. (1983). Efeito do fotoperiodo no ciclo biológico de Diatraea saccharalis. Pesquisa Agropecuária Brasileira, 18(5), 463-472.

Pinheiro, J. C. A., Pádua, L. E. M., Portela, G. L. F. P., Branco, R. T. P. C., Reis, A. S., \& Silva, P. R. R. (2008). Biologia comparada de Spodoptera frugiperda (J. E. Smith, 1797) visando ao seu zoneamento ecológico no Estado do Piauí. Revista Caatinga, 21(2), 197-203.

Reunião Técnica Anual do Milho 62 ${ }^{\mathrm{a}}$, \& Reunião Técnica do Sorgo 45a . (2017). Indicações técnicas para o cultivo de Milho e de Sorgo no Rio Grande do Sul, Safras: 2016/2017, 2017/2018. Brasília, DF: Embrapa.

Rosa, A. P. A., Trecha, C. O., Alves, A. C., Garcia, L., \& Gonçalves, V. P. (2012). Biologia e tabela de vida de fertilidade de Spodoptera frugiperda (J. E. Smith) em linhagens de milho. Arquivo do Instituto Biológico, 79(1), 39-45. https://doi.org/10.1590/S1808-16572012000100006

Sá, V. G. M., Fonseca, B. V. C., Boregas, K. G. B., \& Waquil, J. M. (2009). Sobrevivência e desenvolvimento larval de Spodoptera frugiperda (J. E. Smith) (Lepidoptera: Noctuidae) em hospedeiros alternativos. Neotropical Entomology, 38(1), 108-115. https://doi.org/10.1590/S1519-566X2009000100012

Sarro, F. B. (2006). Biologia comparada de Spodoptera frugiperda (J. E. Smith, 1797) (Lepidoptera: Noctuidae) em milho e em cultivares de algodoeiro (Doctoral dissertation). Retrieved from http://hdl.handle.net/11449/ 105423

Scriber, J. M., \& Slansky Jr, F. (1981). The nutritional ecology of immature insects. Annual Review Entomology, 26, 183-211. https://doi.org/10.1146/annurev.en.26.010181.001151

Silveira Neto, S., Nakano, O., Barbin, D., \& Vila Nova, N. A. (1976). Manual de ecologia de insetos. São Paulo: Ceres.

Souza, A. M. L., Ávila, C. J., \& Parra, J. R. P. (2001). Consumo e utilização de alimento por Diatraea saccharalis (Fabr.) (Lepidoptera: Pyralidae), Heliothis virescens (Fabr.) e Spodoptera frugiperda (J.E. Smith) (Lepidoptera: Noctuidae) em duas temperaturas. Neotropical Entomology, 30(1), 11-17. https://doi.org/ $10.1590 /$ S1519-566X2001000100003

Teixeira, C. G., Jardine, J. G., \& Beisman, D. A. (1997). Utilização do sorgo sacarino como matéria-prima complementar à cana-de-açúcar para obtenção de etanol em microdestilaria. Ciência Tecnologia de Alimentos, 17(3), 221-229. https://doi.org/10.1590/S0101-20611997000300011

Waldbauer, G. P. (1968). The consumption and utilization of food by insects. Advances in Insect Physiology, 5, 229-288. https://doi.org/10.1016/S0065-2806(08)60230-1

\section{Copyrights}

Copyright for this article is retained by the author(s), with first publication rights granted to the journal.

This is an open-access article distributed under the terms and conditions of the Creative Commons Attribution license (http://creativecommons.org/licenses/by/4.0/). 